\title{
Adventure Tourism as a Research Tool in Non-Tourism Disciplines
}

\section{RALF Buckley}

International Chair in Ecotourism Research, Griffith University, Gold Coast 4222, Australia. e-mail: r.buckley@griffith.edu.au

\begin{abstract}
:
Tourism research can gain broader academic recognition if findings from tourism research become relevant to, and cited within, other academic disciplines. Adventure tourism can provide opportunities for ground breaking research on wide-ranging issues such as: motivations for human mobility; individual economic valuation of high-rarity, lowprobability experiences; volunteer assumption of physical personal risk, and its legal consequences; positive and negative effects of tourism on conservation; psychological models of human emotions; the anthropology of interactions between highly disparate human cultures; the use of autoethnography as a research tool; construction of social capital and cohesion; altruistic or competitive behaviour under severe stress; the design of communications systems; establishment and operation of human relationships involving extreme personality types; the physiology of acute stress; and human perceptions of risk and emotion, the passage of time, and the purpose of life. From an academic perspective, adventure tourism is much more than simply a substantial subsector of the mass tourism industry. It is an opportunity to conduct more widely relevant and recognized research, publishable in tourism journals yet also citeable in other disciplines.
\end{abstract}

Keywords: adventure tourism experiences; research tool; cross-disciplinary research.

\section{Introduction}

Patterns and rankings in tourism research, the use of tourism knowledge, and priorities for future tourism research have been explored extensively (Xiao and Smith 2007; Pearce 2009; Hall 2011; Benckendorff and Zehrer 2013; Chang and McAleer 2012; Fennell 2013; Xin et al. 2013; Wardle and Buckley 2014; Williams et al. 2012). The first modern tourism researchers originated in other academic disciplines, and applied the mindsets, methodologies and research literatures of their primary disciplines within the tourism sector. The total number of tourism researchers was small, and tourism journals were in a fledgling state. As the field grew, the number of journals proliferated greatly; and individual students could spend their entire academic career working only in tourism, from Bachelors to Masters 
degree, $\mathrm{PhD}$ to academic appointment. Senior tourism researchers were keen to establish tourism as a recognized research discipline, particularly within grant funding and research assessment agencies. Authors, editors and journal publishers were driven to pay increasing attention to journal impact factors. These circumstances combined to create a self-contained culture of tourism scholarship, where most articles in tourism journals cited publications principally from other tourism journals.

The consequence of these pressures is that whilst tourism research was indeed established as a recognized academic discipline as well as a multidisciplinary field, in the process it became very self-referential (Wardle and Buckley 2014). Indeed, it fragmented into even more selfreferential sub-segments, with almost entirely disjunct literatures of tourism and leisure, events and hospitality, sport and recreation. This is still the current situation. One side effect is that impact factors, even for the top-tier specialist tourism journals, have remained relatively low, because the pool of potentially citing authors is small. The top-ranked science journal, for example, has an impact factor more than 10 times that of the top-ranked tourism journal. In consequence, academics who possessed disciplinary expertise outside tourism itself, e.g. in economics or psychology, published by preference in the primary journals of those disciplines, even if the specific topic was related to tourism. Some of the most highlycited tourism research, in consequence, was published in non-tourism journals. This did have the advantage that researchers in other disciplines became aware, even if only to a small degree, of the existence of tourism research. To date, however, this has not yet lead to any significant outflow of insights or information from tourism journals to other disciplines (Wardle and Buckley 2014).

This is not in itself surprising, if we think of tourism simply as an industry sector. Journals of agriculture, fisheries, forestry, manufacturing or mining are not widely cited outside those specific fields. Tourism, however, is also a significant aspect or component of human behaviour. Particularly if we include travel and tourism more broadly, the field essentially examines how and why people move from place to place. As noted by Wardle and Buckley (2014), there is no fundamental reason why this should be any less significant than studying how people amass, trade and expend resources, studied under the heading of economics; or how they establish social rules of behaviour and resolve resulting conflicts, studied under the heading of law. Overall, Wardle and Buckley (2014) argue that for tourism research to enter a third phase, where findings published in tourism journals are also exported for citation in 
other disciplines, we need to identify and address tourism research questions whose answers also apply beyond the confines of tourism.

\section{Methods}

Here, therefore, the author set out specifically to identify such questions which could be addressed through the study of adventure tourism. The approach taken was to proceed discipline by discipline, identifying potential research questions from adventure tourism and then applying three successive screens, as follows. In the first screen, questions were eliminated if they simply involve the application of another academic discipline within tourism, unlikely to yield exportable results. The second screen was to ask whether each identified question could provide an advance in knowledge within the discipline concerned, relevant beyond the confines of tourism research; so that results would be citable, at least at the level of a tourism case study, in disciplinary journals outside tourism. The third and highest-level screen was to ask whether each question identified is sufficiently fundamental, within the discipline concerned, that it could expect to be cited repeatedly, not simply as a tourism case study, but as a significant addition to academic knowledge irrespective of the sector in which it is grounded.

The questions identified through this approach, and examples of applicable adventure tourism data, are summarized in Table 1, together with relevant references. In the sections below, the author examines these questions further for a small selection of the disciplines and issues listed in Table 1: geography, economics, psychology, and human behaviour.

\section{Geography}

Geography holds a special position in tourism research, since tourism and travel, by definition, incorporate spatial components. In particular, research in tourism and travel focuses on spatial displacement which is both voluntary and temporary. Motivations for travel may include commercial, professional, social and personal reasons. Opportunities for travel differ widely between individuals, depending on financial resources, discretionary time, and political freedoms. All of these have strong geographic components associated with social and cultural differences between countries.

Every outdoor adventure activity also has its own global geography of icon sites, where sufficiently skilled exponents have the greatest opportunity to experience rush (Buckley 
2012), though there is no guarantee of rush on any particular adventure tourism trip. For each adventure tourism activity, we thus have a geography of particular places which attract particular people, at considerable voluntary expense, for the possibility of a very brief but highly valued experience.

From a geographical research perspective, therefore, we can ask what other types of human psychology and behaviour may provide parallels. What other human activities provide such strong attractions to particular places, but only for certain classes of people, and with no guarantee of payoff? Many types of tourism have icon sites, whether for scenery, architecture, wildlife, history or tradition. For most of these, however, there is a high probability of a successful payoff simply from visiting the site, typically from a combination of social capital and individual experience. Certainly, some scenic sites may be more magnificent at particular seasons, but these are known in advance and can be factored into travel plans. Similarly, there are activities such as gambling with very uncertain payoffs, but there is no iconic geography of casinos: they are effectively substitutable.

The closest parallels, perhaps, are in religious tourism, and the thanatourism of historical atrocities. In both these cases, there is indeed a global geography of iconic sites, and at least some tourists may visit them in the hope of personal epiphany or catharsis. That is, whilst there is a basic payoff simply from visiting the site, the high value payoff is uncertain, just as for many forms of adventure tourism. In summary, adventure tourism gives us a geography of places worldwide, determined by natural terrain and weather rather than human habitation or infrastructure, and advertized through specialist channels associated with particular activities, which attract the exponents and practitioners of those activities from around the world, in the hope of a peak experience of lifetime significance.

\section{Economics}

If particular adventure experiences can be valued so highly that people will devote their entire leisure time and budget seeking such experiences, that raises interesting issues of economic valuation. If a surfer is prepared to take multiple live-aboard boat trips to Indonesia or the Maldives, for example, in the hope of a perfect barrel which might last a few seconds at most, that indicates that the value placed on that experience is extremely high. A typical enthusiastic intermediate surfer might surf two hours a day, two days a week for 10 years to build up the skill needed to surf a fast barrelling reef break. That is 2000 hours, which is 
equivalent to more than a year's full time work and corresponding salary value. Add to that the cost of boards, wetsuits, car mileage and surf trips, and (using Western currencies and salary rates), that would represent a total of over $\$ 60,000$ invested for the chance of an experience lasting perhaps three to five seconds at most.

Of course, there are other payoffs along the way, with every wave surfed; but those few seconds in the perfectly shaped barrel are the goal, in the same way that Olympic gold or World Championships are the goal of competitive athletes. Similar considerations apply for other adventure activities, such as whitewater kayakers who take on Class V+ rapids or paddle over waterfalls; or mountaineers who invest a lifetime to stand on top of Mt. Everest. These figures would suggest that to the committed adventure practitioner, the peak experience of surfing the perfect barrel, paddling over a high waterfall, or standing on top of the world's highest mountain, is worth around \$50 million per hour. Of course, most types of peak adventure experience are not directly tradable, and indeed are not purchasable at any price, so this is not a market value. It is, however, an economic value in the sense that it measures the utility placed upon that particular experience by the individuals concerned, based on the market value of resources that they are effectively prepared to trade for it.

We may therefore consider what other types of human experience, or indeed what other goods and services, may be valued at correspondingly high figures. What else, if anything, is so valuable that people will invest a year of their life for a five-second return? More generally, what can the behaviour of adventure tourists in search of such brief, uncertain but highly valued experiences contribute to economic theory related to other goods and services with low probability, low predictability, low substitutability, and high consequences, either positive or negative? There are parallels with high-stakes gambling, or with drilling wildcat wells in oil exploration. There are parallels with an entire class of high-risk behaviours which have been studied under the heading of edgework (Lyng 1990).

There are also parallels with the economic valuation of unique and irreplaceable treasures. Examples include famous artworks, archaeological materials, high-value gemstones, or the last remaining individuals of any rare and endangered plant or animal species. For some people, such things have indefinitely high value, whereas for others, they are of little significance. That is, they may be either priceless or worthless, but they do not have a stable tradable market value. Most standard economic theory, however, is built around the concept 
that there are many potential buyers for any item on sale, with relatively small marginal differences between the prices that different purchasers are prepared to pay. That is, there is substitutability both between items for sale, and between people to buy them. Widely used economic concepts such as demand-supply curves, elasticities of supply and demand, and consumer surplus all have their theoretical roots in this type of market model; and such models can provide accurate predictions of individual human behaviour under circumstances where these assumptions apply.

For applications such as gambling, insurance or auctions, however, simple expected-utility models do not predict human behaviour accurately. More accurate predictions are obtained by psychological models which incorporate human predilections to over- or under-estimate the consequences of low-probability events. Even these models, however, allow for high substitutability: there are many casinos and many gamblers, and there are many insurance policies and many people purchasing them. Even for rare and endangered species, there are still markets, whether legal or black, either for living individuals, or body parts, or hunting licences. The same applies, and indeed it is part of the same market, for a variety of illicit substances which purchasers believe can contribute to their health or longevity, and to various addictive drugs which can provide the purchasers with experiences not otherwise available.

These various examples illustrate three different components of peak adventure tourism experiences, from an economic perspective, namely: (a) high overall rarity; (b) orders of magnitude differences in valuation between individuals; and (c) trading a certain but relatively small upfront payment against a low-probability but very high-value outcome, either a positive outcome gained or a negative outcome avoided. The behaviour of adventure tourists can thus contribute to understanding of human economic behaviour under any or all of these circumstances. In addition, it is a reminder that economics is ultimately not the study of money, but the study of a particular aspect of human behaviour, namely how people allocate resources in order to maximize their aggregate expected net utility. This is only one particular class and driver of human behaviour, and there are other classes with equally powerful psychological drivers. Individual emotions or beliefs can override economic considerations. Adventure tourism provides opportunities to study the mechanisms by which this may occur. 


\section{Psychology}

Given that the icon sites of adventure tourism can sometimes provide experiences which are valued very highly by their practitioners, it would seem that these peak experiences must involve powerful psychological mechanisms. Adventure tourism may thus provide a tool to examine the neurophysiology of the human brain under conditions of thrill, fear, flow or rush. There is an extensive literature on the role of emotion in tourism, and this includes adventure tourism, but it is entirely from a phenomenological perspective. There is also an extensive and highly technical scientific and medical literature on the neurophysiology of human psychological states, including a variety of emotions; but none of this includes adventure tourism activities.

With the recent advent of highly portable electroencephalographic equipment, however, together with real-time data transmission over broadband telephone networks, there are now opportunities to test neurophysiological models of affect in high-stress, high-thrill, high-fear or near-death circumstances, using willing volunteers with no ethical complications. Portable EEG headsets were developed as a mental control system for computer games, but can also be used to monitor emotions. Data transmission systems using standard mobile phones were developed for applications such as aerial photography using small quadrocopter drones, or unmanned aerial vehicles (UAVs); but they could equally be adapted to transmit other forms of electronic data. To date, none of this equipment remains functional if immersed in water, particularly salt water, so it is not yet available for adventure activities such as surfing or whitewater kayaking. It could, however, be adapted for activities such as rock climbing, hang-gliding or base-jumping. Military helmets already transmit real-time point-of-view video back to mission control stations, and it would be a straightforward engineering task to embed the 14 sensors of a standard portable EEG array into such a helmet. This could transmit an emotional record, linked to what an adventure tourism practitioner is seeing, at millisecond resolution. This could well yield some very broad-ranging and fundamental advances in human psychology.

Indeed, this approach could be taken to even more fundamental levels. Human ability to measure time is imprecise. We have various biological clocks; we can detect circadian rhythms; and we can assess duration of commonplace events under unemotional circumstances when all our senses are operational. Our abilities to do this are quite inaccurate, however, which is why we use a variety of mechanical or electronic clocks to 
measure time more reliably. Estimates of time duration are systematically distorted under a variety of particular circumstances, such as general anaesthesia or unconsciousness caused by trauma.

In particular, the experience of extreme fear can create a time dilation effect, when the subject feels that time is passing slowly so that a very brief moment is perceived as an eternity. Several different hypotheses have been proposed for this effect (Eagleman 2008; Stetson et al. 2007; Arstila 2012; Phillips 2013). These are difficult to test, since it seems that a real, unexpected and immediate fear of violent death is needed to activate this perception. Phenomenological research in adventure tourism, however, indicates that some highly skilled exponents who voluntarily take on extremely high-risk, high-skill activities, do indeed experience exactly this effect, presumably because there is indeed a real risk of death associated with such activities. Examples include kayaking over waterfalls or through very difficult and dangerous rapids, surfing very large and powerful waves, or cliff take-offs with a hangglider or base-jumping parachute. The opportunity to use such experiences as a tool to elucidate how humans perceive time could perhaps be the most fundamental contribution of adventure tourism research to other academic disciplines.

\section{Social Behaviour}

In addition to individual psychology such as that outlined above, adventure tourism can provide opportunities to study social psychology and behaviour, under conditions where small groups of either friends or strangers experience discomfort, danger, challenge, or other forms of stress. Tales have been written and movies made about instances of bravery and altruism, or alternatively, instances of breakdown, selfishness and conflict. There does not yet seem to have been any systematic study, however, as to what mechanisms distinguish which of these very different outcomes will occur. For example, relevant factors might include individual personalities, details of physical circumstances, or the history of a particular event: i.e., how the participants got themselves into difficulty.

The factors which distinguish between cooperation and conflict have been studied extensively in both workplace and domestic social relations. There are entire counselling industries which rely on relatively standard sequences of emotional and behavioural response to personal traumas such as divorce, bereavement, or loss of assets or employment. These, however, essentially rely on broad similarities between different individuals under similar 
circumstances. They are not able to make accurate predictions for a single individual, and nor have they examined the neurophysiological processes or the potential evolutionary origins or adaptivity of these various reactions. Of course, the particular sets of stresses associated with adventure tourism, even when things do not go according to plan, are not necessarily the same as for other traumatic life events such as those listed above. They may, however, be intensely stressful; or alternatively, they may be intensely joyful. In each case, there are opportunities to examine social processes, where the findings may well prove relevant to a much broader range of social circumstances.

\section{Conclusions}

The ideas and topics outlined above are all intended to illustrate a single rather simple theme. To take part in adventure tourism, an individual must possess both the opportunity, and a personal motivation to devote time and money to experience a particular type of activity, which may also involve risk. This indicates that such tourists place high value on the adventure tourism experience. This value may be derived either from a social experience during the tour itself, or from social capital as a consequence of the tour experience, or from the personal physical and emotional experience of the activity itself. This provides opportunities to conduct research on all of these aspects.

Adventure tourism, particularly for more highly skilled and practiced exponents, can involve high risks, difficult decisions, stressful social situations, and considerable investment of time and money, in order to create chances to enjoy particular types of brief, emotionally intense and very highly valued experiences associated with the competent performance of a learned skill under highly challenging circumstances. It is argued here that this provides opportunities for research in geography, economics, psychology and human social behaviour which are not readily available elsewhere, and whose results may prove relevant well beyond the confines of adventure tourism itself and that adventure tourism can provide a tool which can help to extend both the practical and the academic relevance of tourism research into other disciplines. It is suggested that such approaches are worth taking, not only in adventure tourism but also in other subsectors of tourism research.

Growth in recognition of any academic discipline, and its journals and practitioners, relies on positive feedback effects. The higher a journal's reputation and impact factor, the higher the quality of research which it can attract, which in turn increases citations and impact factors. 
Tourism research is now well established not only as a broad field of research, but as a defined academic discipline, with numerous discipline-specific journals. No matter how rigorous their refereeing and selective their editorial processes may be, however, the impact factors of these journals are limited by the relatively small number of tourism researchers worldwide, which limits the available pool of potentially citing authors. To increase the size of this pool, in order to boost journal impact factors and thus improve the perceived position of tourism relative to other research disciplines, the first step is for tourism journals to publish more articles which are citeable in other disciplines.

As long as journals in other disciplines have higher impact factors, cross-disciplinary researchers will continue to publish in other disciplines. If more articles in tourism journals are cited externally, however, so that tourism journals gain higher impact factors, then there will be greater incentive for cross-disciplinary researchers to publish preferentially in tourism journals, which in turn will improve the competitive position of tourism relative to longerestablished academic disciplines. Wardle and Buckley (2014) argued that we should search for such opportunities. Main argument, however, here is that at least for adventure tourism, these opportunities exist. Indeed, a recent tourism article on adventure tourism and climate change (Dawson and Scott 2013) has just been cited in the world's top-ranked journal (Morello 2014). Surely there must also be similar opportunities in other segments of tourism research. 


\section{References}

ALLMAN, T. L., MiTTELSTAEDT, R. D., MARTIN, B. and GOLDENBERG, M. (2009). Exploring the Motivations of BASE Jumpers: Extreme Sport Enthusiasts. Journal of Sport and Tourism 14: 229-247.

ANDERSON, L. (2006). Analytic Autoethnography. Journal of Contemporary Ethnography 35: 373-395.

ARSTILA, V. (2012). Time Slows Down During Accidents. Frontiers in Psychology 3(196): $1-10$.

BENCKENDORFF, P. and ZEHRER, A. (2013). A Network Analysis of Tourism Research. Annals of Tourism Research 43: 121-149.

BREIVIK, G. (1996). Personality, Sensation Seeking and Risk Taking among Everest Climbers. International Journal of Sport Psychology 27: 308-320.

BUCKLEY, R. C. (2003). Adventure Tourism and the Clothing, Fashion and Entertainment Industries. Journal of Ecotourism 2: 126-134.

BUCKLEY, R. C. (Ed.) (2004). Environmental Impacts of Ecotourism. Wallingford. CAB International.

BUCKLEY, R. C. (2006a). Adventure Tourism. Wallingford. CAB International.

BUCKLEY, R.C. (2006b). Adventure Tourism Research: A Guide to the Literature. Tourism Recreation Research 31: 75-83.

BUCKLEY, R. C. (2007). Adventure Tourism Products: Price, Duration, Size, Skill, Remoteness. Tourism Management 28: 1428-1433.

BUCKLEY, R. C. (2009). Ecotourism: Principles and Practices. Wallingford. CAB International.

BUCKLEY, R. C. (2010a). Geography. In Buckley, R.C. Adventure Tourism Management. Oxford. Elsevier: 17-30

BUCKLEY, R. C. (2010b). Conservation Tourism. Wallingford. CAB International.

BUCKLEY, R. C. (2010c). Communications in Adventure Tour Products: Health and Safety in Rafting and Kayaking. Annals of Tourism Research 37: 315-332.

BUCKLEY, R. C. (2011). Tourism and Environment. Annual Review of Environment and Resources 36: 397-416.

BUCKLEY, R. C. (2012). Rush as a Key Motivation in Skilled Adventure Tourism: Resolving the Risk Recreation Paradox. Tourism Management 33(4): 961-970.

BUCKLEY, R. C. (2013). Next Steps in Recreation Ecology. Frontiers in Ecology and the Environment 11(8): 399. 
CARNICELLI-FILHO, S., SCHWARTZ, G. M. and TAHARA A. K. (2009). Fear and Adventure Tourism in Brazil. Tourism Management 31(6): 953-956.

CATER, C. (2006). World Adventure Capital. In Buckley, R. C. (Ed) Adventure Tourism. Wallingford. CABI: 429-442.

CHANG, C-L. and McALEER, M. (2012). Citations and Impact of ISI Tourism and Hospitality Journals. Tourism Management Perspectives 1: 2-8.

CHANG, H. (2008). Autoethnography as Method. Walnut Creek, CA. Left Coast.

COHEN, E. (1984). The Sociology of Tourism: Approaches, Issues and Findings. Annual Review of Sociology 10: 373-392.

CROMPTON, J. L. (1979). Motivations for Pleasure Vacations. Annals of Tourism Research 6: 408-424.

DAWSON, J. and SCOTT, D. (2013). Managing for Climate Change in the Alpine Ski Sector. Tourism Management 35: 244-254.

DELLE FAVE, A., BASSI, M. and MASSIMINI, F. (2003). Quality of Experience and Risk Perception in High-Altitude Rock Climbing. Journal of Applied Sport Psychology 15: 82-98.

EAGLEMAN, D. (2008). Human Time Perception and its Illusions. Current Opinion in Neurobiology 18: 131-136.

FENNELL, D. (2013). The Ethics of Excellence in Tourism Research. Journal of Travel Research 52: 417-425.

FAULLANT, R., MATZLER, K. and MOORADIAN, T.A. (2011). Personality, Basic Emotions, and Satisfaction: Primary Emotions in the Mountaineering Experience. Tourism Management 32: 1423-1430.

GIBSON, C. (2008). Locating Geographies of Tourism. Progress in Human Geography 14: 372-390.

GROSS, C. T. and CANTERAS, N. S. (2012). The Many Paths to Fear. Nature Reviews Neuroscience 13: 651-658.

HAEGLER, K., ZERNECKE, R., KLEEMANN, A. M., ALBRECHT, J., POLLATOS, O., BRÜCKMAN, H. and WIESMANN, M. (2010). No Fear No Risk! Human Risk Behavior is affected by Chemosensory Anxiety Signals. Neuropsychologia 48: 3901-3908.

HALL, C. M. (2011). Publish and Perish? Bibliometric Analysis, Journal Ranking and the Assessment of Research Quality in Tourism. Tourism Management 32: 16-27.

KRUSCHWITZ, J. D., SIMMONS, A. N., FLAGAN, T. and PAULUS, M. P. (2012). Nothing to Lose: Processing Blindness to Potential Losses Drives Thrill and Adventure Seekers. NeuroImage 59: 2850-2859. 
LIPSCOMBE, N. (2007). The Risk Management Paradox for Urban Recreation and Park Managers: Providing High Risk Recreation within a Risk Management Context. Annals of Leisure Research 10: 3-25.

LYNG, S. (1990). Edgework: A Social Psychological Analysis of Voluntary Risk Taking. American Journal of Sociology 95: 851-856.

MCDONALD, J. (2003). The Financial Liability of Park Managers for Visitor Injuries. In Buckley, R. C., Pickering, C. and Weaver, D. (Eds) Nature-Based Tourism, Environment and Land Management. Wallingford. CAB International: 35-50.

MCGILLIVRAY, D. and FREW, M. (2007). Capturing Adventure: Trading Experiences in the Symbolic Economy. Annals of Leisure Research 10: 54-78.

MORELLO, L. 2014. Winter Olympics: Downhill Forecast. Nature 506: 21-22.

MORGAN, D. J. (2010). Adventure Tourism Activities in New Zealand: Perceptions and Management of Client Risk. Tourism Recreation Research 25: 79-89.

NIEDENTHAL, P. and BRAUER, M. (2012). Social Functionality of Human Emotion. Annual Review of Psychology 63: 259-285.

PEARCE, P.L. Tourism Research and the Tropics: Further Horizons. (2009). Tourism Recreation Research 34: 107-121.

PHILLIPS, I. (2013). Perceiving the Passing of Time. Proceedings of the Aristotelian Society 113(3): 1-25.

POMFRET, G. (2008). Mountaineering Adventure Tourists: A Conceptual Framework for Research. Tourism Management 27:113-123.

SHARPE, R. (2005). "Going Above and Beyond": the Emotional Labor of Adventure Guides. Journal of Leisure Research 37: 29-50.

STETSON, C., FIESTA, M. and EAGLEMAN, D. (2007). Does Time Really Slow Down During a Frightening Event? PLOS ONE 2(12): e1295.

STRONZA, A. (2001). Anthropology of Tourism: Forging New Ground for Ecotourism and other Alternatives. Annual Review of Anthropology 30: 261-284.

TOLICH, M. (2010). A Critique of Current Practice: Ten Foundational Guidelines for Autoethnographers. Qualitative Health Research 20: 1599-1610.

VAN WESTERLOO, D., CHOI, G., LÖWENBERG, E. C., TRUIJEN, J., DE VOS, A. F., ENDERT, E., MEIJERS, C.J.M., ZHOU, L., PEREIRA, M.P.F.L., QUEIROZ, K.C.S., DIKS, S. H., LEVI, M., PEPPELENBOSCH, M. P. and VAN DER POLL, T. (2011). Acute Stress Elicited by Bungee Jumping Suppresses Human Innate Immunity. Molecular Medicine 17: 180-188. 
WARDLE, C. and BUCKLEY, R. C. (2014). Tourism Citations in Other Disciplines. Annals of Tourism Research 10.1016/j.annals.2014.01.002.

WILLIAMS, P.W., STEWART, K. and LARSEN, D. (2012). Towards an Agenda of HighPriority Tourism Research. Journal of Travel Research 51: 3-11.

XIAO, H. and SMITH, S.L.J. (2007). The Use of Tourism Knowledge: Research Propositions. Annals of Tourism Research 34: 310-331.

XIN, S., TRIBE, J. and CHAMBERS, D. (2013). Conceptual Research in Tourism. Annals of Tourism Research 41: 66-88.

YERGER, D. M. (2005). High-risk Recreation: The Thrill that Creates a Statutory and Judicial Spectrum of Response and Drives the Dichotomy in Participant and Provider Liability. Suffolk University Law Review 38: 687-706. 
Table 1. Potential Cross-disciplinary Research Using Adventure Tourism

\begin{tabular}{|c|c|c|}
\hline Discipline & Topic & Adventure tourism data \\
\hline Geography & motivations for human mobility & $\begin{array}{l}\text { changing geography of icon adventure destination } \\
\text { in domestic and international travel to icon sites fo } \\
\text { activities }\end{array}$ \\
\hline Economics & $\begin{array}{l}\text { individual economic valuation of } \\
\text { high-rarity, low-probability } \\
\text { experiences }\end{array}$ & $\begin{array}{l}\text { revealed valuation of short-duration peak experien } \\
\text { on individual investment to achieve them, partitior } \\
\text { stated valuations and quantitative data on frequenc } \\
\text { duration of such experiences }\end{array}$ \\
\hline Law & $\begin{array}{l}\text { voluntary assumption of personal } \\
\text { physical risk; liability and legal } \\
\text { consequences of risk }\end{array}$ & $\begin{array}{l}\text { litigation associated accidents and injury against to } \\
\text { operators and landholders; legislation for commer } \\
\text { adventure tourism, e.g. skier safety, horse riding. }\end{array}$ \\
\hline Ecology & $\begin{array}{l}\text { contributions of adventure tourism } \\
\text { to conservation; ecology of } \\
\text { repeated stress-recovery cycles }\end{array}$ & $\begin{array}{l}\text { wildlife adventure tourism as a source of conserva } \\
\text { support and finance; disturbance and recreation im } \\
\text { heavily used adventure sites }\end{array}$ \\
\hline $\begin{array}{l}\text { Anthropology } \\
\text { and Ethnography }\end{array}$ & $\begin{array}{l}\text { interactions between highly } \\
\text { disparate cultures; development of } \\
\text { analytical autoethnography as a } \\
\text { research tool }\end{array}$ & $\begin{array}{l}\text { short-term perceptions and longer-term social and } \\
\text { changes in otherwise isolated local communities a } \\
\text { sites used by highly-equipped adventure tourists; } \\
\text { autoethnography of adventure as a tool in psychol }\end{array}$ \\
\hline
\end{tabular}




\begin{tabular}{|c|c|c|}
\hline $\begin{array}{l}\text { Sociology and } \\
\text { Human } \\
\text { Behaviour }\end{array}$ & $\begin{array}{l}\text { construction and maintenance of } \\
\text { social capital; establishment and } \\
\text { breakdown in social cohesion; } \\
\text { sociology of fashion and its } \\
\text { dynamics; altruistic or competitive } \\
\text { behaviour under severe stress }\end{array}$ & $\begin{array}{l}\text { operation and outcomes of group-formation proce } \\
\text { use of adventure tourism as a team building mecha } \\
\text { conflicts and arguments within groups; emotional } \\
\text { guides; cases of selfless behaviour during disasters }\end{array}$ \\
\hline Communications & $\begin{array}{l}\text { design of minimal-content high- } \\
\text { reliability communication systems } \\
\text { over intermittent channels }\end{array}$ & safety and emergency signals in climbing, diving, \\
\hline Personality & $\begin{array}{l}\text { establishment and operation of } \\
\text { human relationships involving } \\
\text { extreme personality types }\end{array}$ & $\begin{array}{l}\text { consequences for domestic and professional relati } \\
\text { where one or more members insists on devoting ti } \\
\text { funds to high-risk recreation; changes in adventur } \\
\text { following significant life events such as birth of ch }\end{array}$ \\
\hline Psychology & $\begin{array}{l}\text { individual perception cf } \\
\text { quantitative evaluation of risk; } \\
\text { psychological models of human } \\
\text { emotions; human perceptions of } \\
\text { time }\end{array}$ & $\begin{array}{l}\text { phenomenological perception and neurophysiolog } \\
\text { monitoring of emotions experienced under conditi } \\
\text { high thrill, fear, joy, rush, risk; and accelerated abi } \\
\text { perceive and react under immediate threat of immi } \\
\text { or injury }\end{array}$ \\
\hline $\begin{array}{l}\text { Physiology, } \\
\text { Biochemistry }\end{array}$ & $\begin{array}{l}\text { addiction and biochemical } \\
\text { dependency effects of acute stress } \\
\text { on immune system response }\end{array}$ & blood chemistry of active adventure tourists \\
\hline Philosophy & $\begin{array}{l}\text { individual human perceptions of the } \\
\text { purpose of life }\end{array}$ & $\begin{array}{l}\text { lifestyle decisions, trade-offs and stated views by } \\
\text { adventure tourism guides, clients and practitioners }\end{array}$ \\
\hline
\end{tabular}

